\title{
The Croatian Model of University Education for Nurses
}

\section{Stipan Janković, Sonja Koren, Matea Šarić, Rahela Orlandini, Vesna Antičević, Deana Švaljug and Ante Buljubašić}

\author{
Department of Health Studies, University of Split, Croatia \\ *Corresponding author: Stipan Janković, Department of Health Studies, University of Split, Ruđera \\ Boškovića 31, 21000 Split, Croatia, Tel: +38521564801,E-mail: stipan.jankovic@ozs.unist.hr
}

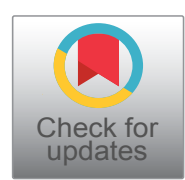

\begin{abstract}
Following the example of Dutch "Model of macro-efficiency of the higher education system" in 2011 the University Department of Health Studies was founded in Split. It is fully integrated with the University of Split (legal and economic services, human resources...). In the course of preparing the curriculum of university study programme in Nursing, for both the undergraduate and graduate university levels, attention was paid to compliance with the provisions of Directive 2005/36/EC and Croatian and European qualification framework, based on defined outcomes of education process at the sixth and seventh level of education, according to the $3+2$ model for a Bachelor or Master in Nursing.

University undergraduate and graduate study programmes in Nursing aim at acquiring knowledge, skills and competences necessary to work effectively in contemporary health care systems, as well as the acquisition of academic degrees in nursing, in accordance with the principles defined in documents and recommendations of the Bologna process. University Department of Health Studies has 23 teaching bases. The largest are Clinical Hospital Centre Split, Teaching Public Health Institute of Split and Dalmatia County and Community Health Centre of Split and Dalmatia County. The courses are delivered by 270 to 300 teachers and associates and 100 mentors, which indicates a very favourable ratio of teachers to the number of students. After final examination and defending of the thesis, pursuant to the Act on Academic and Professional Titles and Academic Degrees the student is awarded the title of Bachelor in Nursing for independent work in the health care system.
\end{abstract}

\section{Keywords}

Nursing, Health studies, Competencies, Learning outcomes

\section{Introduction}

University Department of Health Studies, University of Split was founded in 2011 as a successor of Professional Health Studies organized at the School of Med- icine in Split, as a logical continuation of improving the system of education of health professions on the one hand caused by entering the European Union, and adapting to the European standards, but on the other hand by the need to acquire the knowledge and skills necessary for providing the best possible care for patients in all aspects of healthcare.

Following the example of Dutch "Model of macro-efficiency of the higher education system" [1-3] in 2011 the University Department of Health Studies was founded in Split. Five undergraduate university departments and the undergraduate university study programmes in Nursing, Midwifery, Medical Laboratory Diagnostics, Physiotherapy and Radiologic Technology and three graduate university study programmes in Nursing, Physiotherapy and Radiologic Technology were established with the intention of establishing the remaining two in the near future. University Department of Health Studies is fully integrated with the University of Split (legal and economic services, human resources...).

The existing curricula of various university study programmes and qualification standards are structured according to the recommendations, directives and regulations of the European Union and the World Health Organization and adjusted to the specificities of the educational process in the Republic of Croatia. As such, they are compatible with similar programmes in the member states of the European Union and enable the mobility of students and teachers. In particular, the curriculum of the university study of Nursing, considering that this is a regulated profession [1], is related to the regulation of nurse education, harmonization of the programmes, the minimum conditions for nurse

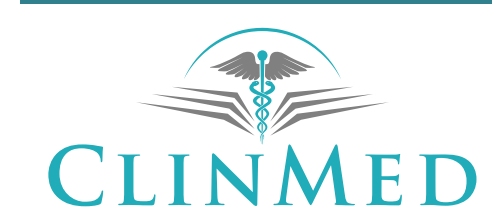

INTERNATIONAL LIBRARY

Citation: Janković S, Koren S, Šarić M, Orlandini R, Antičević V, et al. (2018) The Croatian Model of University Education for Nurses. Int Arch Nurs Health Care 4:093. doi.org/10.23937/2469-5823/1510093 Accepted: May 23, 2018: Published: May 25, 2018

Copyright: (c) 2018 Janković S, et al. This is an open-access article distributed under the terms of the Creative Commons Attribution License, which permits unrestricted use, distribution, and reproduction in any medium, provided the original author and source are credited. 
education, and the competences in the member states, as provided for in Directive 2005/36/EZ [2,3]. In the course of preparing the curriculum of university study programme in Nursing, for both the undergraduate and graduate university levels, attention was paid to all parameters with maximum compliance with the provisions of Directive 2005/36/EC and compliance with Croatian and European qualification framework [4,5], based on defined outcomes of education process at the sixth and seventh level of education, according to the $3+2$ model for a Bachelor or Master of Nursing.

\section{Manuscript Body Text}

University Department of Health Studies, University of Split in 2014 requested from Ministry of Science, Education and Sports their assessment on harmonization of the undergraduate study programme in Nursing with Directive 2005/36/EC of the European Parliament and the Council on the recognition of professional qualifications and Act on Regulated Professions and Recognition of Foreign Professional Qualifications [6,7]. After thematic evaluation of the study programmes in the healthcare field conducted by the Agency for Science and Higher Education (ASHE), the insight into the review of the undergraduate university study programme in Nursing and opinion on the results of the thematic evaluation of the University Department of Health Studies, University of Split, the Ministry of Science, Education and Sports established that the undergraduate university study programme in Nursing comply with the provisions of Article 40 of Directive 2005/36/EC of the European Parliament [5] and the Council EC of 7 September 2005 on the recognition of professional qualifications [8] in the part that regulates the required duration of education, the proportion of theoretical and practical training and minimum competences acquired by completing the study programme.

University undergraduate and graduate study programmes in Nursing aim at acquiring knowledge, skills and competences necessary to work effectively in contemporary health care systems, as well as the acquisition of academic degrees in nursing, in accordance with the principles defined in documents and recommendations of the Bologna process [9]. The courses are delivered in modules. Working week comprises an average of 25-35 teaching hours (lectures, seminars, exercises...) and 25-35 hours of individual work. Teaching methodology corresponds to the most modern pedagogical recommendations: Lectures, seminars, clinical problem solving, work in small groups, practical work in the laboratory, in the simulation laboratory, in-patient, public health and clinical practice and individual work. Exams are taken at the end of each module. The quality and success of every course is assessed at the end of the module by students and teachers, the analysis of exam success rate, report of the Teaching Committee and external evaluation (visits by the quality control teams of the National Agency for Quality Control, external evalu- ation and self-analysis).

Taking into consideration Directive 2005/36/EC [5,8], stating that nursing education must have learning outcomes that ensure planning, implementation, organization and evaluation of health care, and the above-mentioned legal provisions, it can be concluded that the outcomes of the sixth level of the European/Croatian Qualifications (EQF/HKO) framework [10-12] fully meet these requirements for the education of nurses. The European Qualifications Framework (EQF) [11,12], in accordance with which the Croatian Qualifications Framework (HKO) [5,6] was adopted, is a system for harmonizing the educational systems of European countries. It aims, since it was formally promoted in 2008, to encourage the mobility of European citizens and to enable lifelong learning processes. Competences of nurses according to European legislation on regulated professions correspond to the learning outcomes of the $6^{\text {th }}$ level of European and Croatian Qualifications Framework and, consequently, the first level of higher education.

The most important and widely accepted thesis of nursing eduction is that nursing is an independent, clearly defined profession, nurses are not just support staff assisting doctors but well-educated professionals with clearly defined activities and responsibilities in medical teams. Nursing education is a continuation of secondary school education and it starts at the age of 18 , following 8 years of primary and 4 years of secondary education, and education for state registered and fully licensed nurses has to be delivered at university level. Nursing education lasts for at least three years comprising 4,600 hours of teaching and study. Studying is evenly distributed between theoretical and practical teaching with required individual work, and 4,600 hours of teaching and study corresponds to 180 ECTS credits. The practical teaching of 2,503 hours takes place in the clinical teaching bases where students in direct contact with patients, under the supervision of a mentor, acquire the necessary knowledge and skills and in the laboratory of clinical skills in which students prepare to work with patients on the latest models and simulators for health care. University Department of Health Studies has 23 teaching bases. The largest are Clinical Hospital Centre Split, Teaching Public Health Institute of Split and Dalmatia County and Community Health Centre of Split and Dalmatia County. The courses are delivered by 270 to 300 teachers and associates and 100 mentors, which indicates a very favourable ratio of teachers to the number of students. After final examination and defending of the thesis, pursuant to the Act on Academic and Professional Titles and Academic Degrees the student is awarded the title of Bachelor in Nursing, abbreviated univ.bacc. (BN), and to the state authorisation for independent work in the health care system.

Competences the nurses have upon completing undergraduate university study programme of Nursing 
make them fully competent for independent individual and team work in the health system including planning, organization and providing health care on the basis of acquired knowledge and skills. It also enables participation in team work and professional communication with other stakeholders in the health sector, including participation in practical education of health personnel based on acquired knowledge and skills. Upon completing the undergraduate nursing, a bachelor of nursing is able to explain to patients healthy lifestyle and appropriate self-care, implement immediate life-saving measures independently and implement measures in emergency and dangerous situations. The bachelor of Nursing is qualified to provide advice and instructions to people in need of health care and their family and support them, develop, analyse and assess the quality of health care by respecting nature and ethics of the profession and of the general principles of health and health care.

The need for education of Masters of Nursing Science results from the recommendations of the World Health Organization [13], the Bologna Declaration [9] the Munich Declaration [14] and the EU Directive [5,8]. According to these recommendations, nurses are required to be not only the bearers of healthcare and rehabilitation of patients, with the aim of satisfying all their needs and enabling the greatest possible degree of their independence during their stay in the health institutions, but also to provide medical care and rehabilitation after the discharge from health facilities, and implementation of primary and secondary prevention of disease. The Master's study programme in nursing allows the development of analytical skills at a higher level, a wider scope of thinking, better abilities in expressing opinions and attitudes, better implementation of theory into practice and finally development of advanced skills in the nursing profession. With this education, Master in Nursing is able to provide better healthcare, better organize and evaluate the provision of hospital and outpatient healthcare, including disease prevention and health promotion. Finally, they are trained to give lectures within the education programmes in nursing. Under the Master's programme, each student should acquire the ability to analyze, connect and use knowledge through formal courses, seminars, hospital practice or individual work and be trained for an independent lifelong learning and professional development.

Enrolment requirements to the graduate university study programme in Nursing are: Completed undergraduate university study programme in nursing, 180 ECTS credits, grade average score of 4.0 and above at undergraduate level, grade average score of 3.0 and above at undergraduate level with written references of three university professors, at least one year of professional work in relevant institutions, the ranking list is based on average grade scores from the undergraduate level and differential module. Duration of the study programme is two academic years, number of study hours is on the average about 1.500 (40\% of theory $+60 \%$ of practice) per year. The curriculum is compatible with the Bologna process [6] and similar study programmes in the EU member states and enables mobility of students and teachers. Since 2012 the mobility of students, teachers and non-teaching staff from Sør-Trøndelag University College in Trondheim is achieved through Erasmus programme. Students and teachers of Saint Xavier University, Chicago, USA visited the UDHS on two occasions in 2012 and in 2014 as well as many other European teachers who expressed their wish to be introduced to our study programmes.

University Department of Health Studies considers its social responsibility participation of its employees, associates and students in volunteer activities and charity work. Since 2011, the UDHS has participated in numerous humanitarian actions of the University of Split but has also started a number of independent humanitarian actions in which students could develop their professional and social skills by serving the community. In 2015 the Association of Graduates of the University Department of Health Studies, University of Split - Alumni of the UDHS was founded. Alumni of the UDHS is a voluntary organization joined by those who have completed undergraduate or graduate study programmes or still study at the University Department of Health Studies in Split, in order to achieve lasting and mutual benefit and share common interests, such as establishing and maintaining a connection between the UDHS and its students, development of the UDHS, University of Split as an institution, encouraging development of professional, scientific and practical activities of its members, affirmation of the graduates, participation in international scientific and professional exchange and establishing contacts with associations of graduates at home and abroad, protection of professional interests of graduates in accordance with the Code and the rules of the professional conduct, organization and implementation of voluntary and humanitarian work, contributing to the realization of a modern, free, democratic, plural and tolerant, non-violent society.

The logical continuation of rapid and further development of the UDHS, the first university department of health studies organized in this way in Croatia, included an application for the project launched by the Ministry of Science, Education and Sports, funded by the European Structural Fund. In line with the project on the further quality improvement in higher education using the Croatian Qualifications Framework (CQF) [11,12] as an instrument that connects learning outcomes with labour market needs and the European Qualifications Framework (EQF) [10], the UDHS is the holder of the project "Development of occupational standards/qualifications with improvement of health study programmes". The project is underway and includes development of occupational standards (competences required for health professions) and Qualification Standards (structure and content of qualifications achieved 
upon studying) in order to effectively align education with labour market needs. The special value of the project lies in developing graduate study programmes for Midwifery and Medical Laboratory Diagnostics. In accordance with development strategies and health care professionals' needs to adapt to the changing needs of patients, demographic conditions and the health systems of the EU countries, the project anticipates introduction of the additional test of personality traits and emotional competences relevant for performing health professions as part of the selection procedures for enrolment in health studies, together with the success achieved in previous education. The plan is also to implement the Social Skills Training for undergraduate students to develop their social skills and prepare for work with patients. The outcomes of the project will enable further development of the quality of studying at the University Department of Health Studies, offer highly educated health professionals to the health care institutions in the Republic of Croatia and the EU, multidirectional mobility of present and future generations of students, better understanding and mutual recognition of qualifications among health professionals in the EU and Croatia, and increasing the quality of health services as well as the opening of doctoral studies in nursing.

These doctoral studies should focus on research and developing a doctoral dissertation and formal ex cathedra teaching should be reduced to a minimum; teaching should be tailored to the individual needs and therefore should be flexible and individualized, relying on elective courses and courses outside home colleges and universities as well, and; all forms of learning should be based on principles and techniques of evidence based medicine [15].

\section{References}

1. De Boer H, Jon F (2009) Higher education governance reforms across Europe. Center for Higher Education Policy Studies.
2. De Boer Harry F, Jürgen Enders, Liudvika Leisyte (2007) Public Sector Reform in Dutch Higher Education: The Organizational Transformation of the University. Public Administration 85: 27-46.

3. Dw Weert E, Boezerooy $P$ (2007) Higher education in the Netherlands. The higher education monitor report.

4. Janković S, Mihanović F, Šimunović V (2010) The croatian model of university education for helth profesionals. Coll Antropol 34: 1481-1485.

5. (2005) Directive 2005/36/EC of 7 September 2005 on the recognition of professional qualifications. The European Parliament and of the Council 48: 22.

6. NN 124/09. Croatian Official Journal.

7. NN 45/11. Croatian Official Journal.

8. (2007) The role of European codes of conduct European Communities.

9. (1999) The Bologna Declaration of 19 June 1999. Joint declaration of the European Ministers of Education.

10. (2008) The European Qualifications Framework for lifelong learning (EQF). European Commission, Luxembourg.

11. (2009) Croatia Qualifications Framework. Government of the Republic of Croatia.

12. NN 22/13. Zakon o Hrvatskom kvalifikacijskom okviru.

13. Spajić-Vrkaš $\vee$ (2001) Obrazovanje za ljudska prava i demokraciju. Zbirka međunarodnih i domaćih dokumenata. Projekt Obrazovanje za mir i ljudska prava za hrvatske osnovne škole Hrvatsko povjerenstvo za UNESCO. Zagreb.

14. (2000) Munich Declaration: Nurses and Midwives: a Force for Health (Minhenska deklaracija: Medicinske sestre i babice: Snaga za zdravstvo), 2000. Kopenhagen, Regionalna kancelarija SZO za Evropu.

15. Marušić M, Mimica M, Mihanović F, Janković S (2013) Doctoral degree in health professions: Professional needs and legal requirement. Acta Med Acad 42: 61-70. 